\title{
Quality of work life in primary care of nursing professionals in public health clinics in Tampico, Mexico
}

\author{
Nancy L. González-Cruz ${ }^{* 1}$, Maria I. Peñarrieta-de Córdova ${ }^{1}$, Hortensia Castañeda-Hidalgo ${ }^{1}$, Florabel Flores-Barrios ${ }^{1}$, \\ Tranquilina Gutierrez-Gomez ${ }^{1}$, Frida Caballero-Rico ${ }^{2}$ \\ ${ }^{1}$ Tampico School of Nursing, Autonomous University of Tamaulipas, Tamaulipas, México \\ ${ }^{2}$ Direccion de Investigacion, Autonomous University of Tamaulipas, Tamaulipas, México
}

Received: February 18, 2016

DOI: $10.5430 /$ jha.v5n3p90
Accepted: March 27, $2016 \quad$ Online Published: April 6, 2016

URL: http://dx.doi.org/10.5430/jha.v5n3p90

\begin{abstract}
Background: Having a high Quality of Work Life (QWL) has a positive influence in care quality, however, in Mexico, little is known about QWL and even less in health care professionals and primary care. This study aims to describe strengths and areas of improvements in QWL in nursing professionals who work in primary care of Jurisdiction No. 2 in Tampico, Tamaulipas, Mexico. Methods: Cross-sectional analytical study. The CVT-GOHISALO instrument was applied, which measures QWL.

Results: The study sample was composed by 67 women (95.7\%) and 3 men (4.3\%). The average age was 39 years old, ranging from 23 to 69 years old. A $57.1 \%$ reported living with a partner; 54\% had a full time job; and $78.6 \%$ had only one job. The results of the present study showed that dissatisfaction can be found in nursing professional's QWL in public health clinics in all dimensions. Those dimensions with the greatest dissatisfaction were Inclusion in the working place, Personal development and Well-being achieved through work. The dimensions with less dissatisfaction were Institutional support, Free-time management, Work satisfaction, Safety at work.

Conclusions: This study is the first attempt to determine the QWL of nursing professionals of primary care clinics in Tampico, Tamaulipas.
\end{abstract}

Key Words: Quality of work life, Nursing in public health, Primary care

\section{INTRODUCTION}

Due to the changes in health status in the population, primary care has become a priority in guiding health systems development. ${ }^{[1]}$ Health care personnel have a key role for this work. Since nursing personnel are the biggest group that works in public health institutions, they increasingly become essential in primary care, community health and other non-hospital roles. ${ }^{[2]}$
In this level, the role of a nurse includes functions such as to encourage healthy behavior, work with community groups, promote agreements between groups, organize the main activities for preventive health, manage vaccination programs, implement actions aimed to control a healthy environment, implementations to maintain health, monitor and control infectious and non-infectious diseases (diabetes, high blood pressure, e.g.), as well as to detect educational needs and development of health education programs for health and

\footnotetext{
*Correspondence: Nancy L. González-Cruz; Email: nancyglz_14@hotmail.com; Address: Privada Oceano 103, Zip Code 89080, Tampico, Tamps,
} Mexico. 
self-care. ${ }^{[3,4]}$ These activities are part of the essential functions in public health according to the Pan American Health Organization (PAHO). ${ }^{[2]}$ Therefore, studies have suggested that with an appropriate training and support, nurses in primary care can contribute significantly in reinforcing health public services, increasing quality in crucial functions of public health and developing the health of the population. ${ }^{[5]}$

However, despite there are many activities a nurse works on, these are not always fulfilled as they should be; this is due to the working conditions such as overburden, multitasking, among others. These conditions create dissatisfaction for the work as described by several studies conducted in Mexico and Latin America. ${ }^{[6-8]}$ It has been reported that nurses that feel satisfied with their work feel motivated and give a better service that those who perceive a low work satisfaction. ${ }^{[9,10]}$

Studies aimed for healthcare personnel in primary care conducted worldwide in places such as China and Canada; ${ }^{[11,12]}$ strengthen the evidence that work overburden, stress and burnout are important predictors of work dissatisfaction. This has also been described in other studies that have come to the conclusion that nursing profession is among those with highest burnout risk. ${ }^{[13]}$

In Mexico, as far as primary care is concerned, nursing personnel role has not been fully grasped. Even when their education allows them to take over some of the populace's care needs and they are also the personnel in contact with the patient, they continue being helpers to the medical personnel. Experience in other countries shows the benefits in health results and waiting times of allowing greater nursing personnel participation in service delivery. ${ }^{[14]}$

Another issue in Mexico is the number of working nurses in primary care. ${ }^{[15]}$ In average there is 1 nurse for every 2,000 - 6,000 people, which are under figures established by the PAHO regional goals which say there should be 25 nurses for every 10,000 people. ${ }^{[16]}$ Work overburden for the personnel working in this sector is a consequence of lack of human resources in primary care, but it also carries low work satisfaction perception; this is also due to the inadequate infrastructure and resources, lack of assessment in the workplace and the feeling of being unrecognized professionally and financially. ${ }^{[6]}$

All of these aspects mentioned before (labor conditions) could interfere in the quality of work life (QWL) of the nursing personnel that works in primary care. The QWL should be understood as a multidimensional concept that is integrated, through work and under professionals' perception. QWL is achieved when employees understand that the following personal needs are fulfilled: institutional support, safety and integration in the workplace and self-satisfaction, wellPublished by Sciedu Press being achieved through the working activity and personal development, as well as quality of free time management. ${ }^{[17]}$

It is well known that having a high work life quality has a positive influence in care quality, where personnel can develop better and the organization can minimize control mechanisms. ${ }^{[18]}$ However, in Mexico, little is known about QWL and even less in health care professionals and primary care. Among the few studies about QWL is the one conducted by González, ${ }^{[17]}$ who is the instrument's author, in which it is showed that dissatisfaction in all the QWL dimensions was elevated. Due to the small existent evidence it is important to generate more evidence and this study aims to determine the QWL in nursing personnel in primary care in health clinics of Jurisdiction No. 2 in Tampico, Tamaulipas, Mexico.

\section{MeThODS}

This was a cross-sectional descriptive quantitative study. Sample was made up by $100 \%$ of nursing professionals with a Bachelor degree in Jurisdiction No. 2 in Tampico, Tamaulipas. There were a total of 84 Bachelors in Science of Nursing (BSN). The response rate was $83 \%$.

Jurisdiction No. 2 has 1 administrative building and 16 public health clinics distributed across Tampico City and Madero City, in Tamaulipas, Mexico. This distribution is on Table 1.

\subsection{Inclusion criteria}

Bachelor degree in Nursing that worked at the Jurisdiction No. 2 in Tampico and had been working in primary care during 6 months or more.

\subsection{Exclusion criteria}

Nursing who were on holidays, work incapacity or on leave.

\subsection{Measuring instrument}

The "CALIDAD DE VIDA EN EL TRABAJO "CVTGOHISALO" instrument developed by González et al. ${ }^{[19]}$ was used; it has been validated in Mexico. Its reliability is proved via Cronbach's alpha: 0.9527 which is formed by 74 items and 7 dimensions: work institutional support; safety at work; inclusion in the workplace; work satisfaction; wellbeing achieved through work; personnel development and free time management.

During the interpretation of the instruments, the seven dimensions could be assessed independently; the score is presented in McCalls' $\mathrm{T}$ values or percentiles. This is, a percentile 50 would represent average locations of gross score and a score 10 is established as a deviation value. In this manner, scores under T40 would represent a risk of imbalance in work life quality, as shown in Table 2. 
Table 1. Distribution of the BSN staff per clinic

\begin{tabular}{|c|c|c|c|c|}
\hline Health clinic & Bachelor & Specialist & Master & Total \\
\hline Cárdenas González & 2 & & & 2 \\
\hline Rev. Verde & 1 & & & 1 \\
\hline Borreguera & 3 & 1 & & 4 \\
\hline Esfuerzo Obrero & 1 & & & 1 \\
\hline Laguna de la Puerta & 1 & & & 1 \\
\hline Tancol & 3 & & & 3 \\
\hline Vicente Guerrero & 1 & & & 1 \\
\hline Las Américas & 1 & & & 1 \\
\hline Morelos & 2 & & & 2 \\
\hline Luis Echeverría & 1 & & & 1 \\
\hline Nvo. Amanecer & 1 & & & 1 \\
\hline Miradores de la Presa & 2 & & & 2 \\
\hline Francisco Villa & 1 & & & 1 \\
\hline Carmen Romano de López Portillo & 3 & & & 3 \\
\hline Madero & 18 & & & 18 \\
\hline Tampico & 10 & 2 & 3 & 15 \\
\hline Jurisdicción & 24 & & 3 & 27 \\
\hline Total & 75 & 3 & 6 & 84 \\
\hline
\end{tabular}

Note. Source: Jurisdiction No. 2

Table 2. Interpreting the instrument "QWL CVT-GOHISALO"

\begin{tabular}{|c|c|c|c|c|c|c|c|}
\hline Score $(T)$ & $\begin{array}{l}\text { 1. Institutional } \\
\text { support at work }\end{array}$ & $\begin{array}{l}2 \text {. Safety } \\
\text { at work }\end{array}$ & $\begin{array}{l}\text { 3.Workplace } \\
\text { inclusion }\end{array}$ & $\begin{array}{l}\text { 4. Satisfaction } \\
\text { for the work }\end{array}$ & $\begin{array}{l}\text { 5. Well-being achieved } \\
\text { through work }\end{array}$ & $\begin{array}{l}\text { 6. Personal } \\
\text { development }\end{array}$ & $\begin{array}{l}\text { 7. Free time } \\
\text { management }\end{array}$ \\
\hline 99 & 56 & 60 & 40 & 44 & 44 & 32 & 20 \\
\hline 90 & 49 & 54 & 40 & 44 & 42 & 32 & 20 \\
\hline 80 & 45 & 48 & 38 & 42 & 41 & 30 & 19 \\
\hline 70 & 41 & 42 & 36 & 40 & 40 & 28 & 18 \\
\hline 60 & 37 & 36 & 34 & 38 & 39 & 26 & 17 \\
\hline 50 & 33 & 30 & 32 & 36 & 38 & 24 & 16 \\
\hline 40 & 29 & 24 & 30 & 34 & 37 & 22 & 15 \\
\hline 30 & 25 & 18 & 28 & 32 & 36 & 20 & 14 \\
\hline 20 & 21 & 12 & 26 & 30 & 35 & 18 & 13 \\
\hline 10 & 17 & 6 & 24 & 28 & 34 & 16 & 12 \\
\hline 1 & 4 & 5 & 8 & 5 & 23 & 8 & 3 \\
\hline
\end{tabular}

Note. Source: González et al. ${ }^{[19]}$

\subsection{Ethical consideration}

Authorization from the ethics committee in the research department of the School of Nursing at the Universidad Autónoma de Tamaulipas campus Tampico and the $2^{\text {nd }}$ Health Jurisdiction was requested. Data was collected in the statistics software SPSS version 17. Descriptive statistic, frequencies and rates were used.

After informing them about the study's objectives, the participants were asked to sign an informed consent before completing the questionnaire. The confidentiality of the study was guaranteed at all times as the names of the participants were not included.

92

\section{RESULTS}

Study sample was composed by 67 women $(95.7 \%)$ and 3 men $(4.3 \%)$. The average age was 39 years old, ranging from 23 to 69 years old. A $57.1 \%$ reported living with a partner, either in marriage or cohabitation. Only $35.3 \%$ has a steady employment (social security, labor benefits and are accumulating retirement years), the other $64.7 \%$ has temporary employment contracts to be renewed every 6 months as shown in Table 3.

There was a dissatisfaction rate in all dimensions $(<\mathrm{T} 40)$, as shown in Table 4. Dimensions which resulted in highest rates under T40 values were dimensions 3 (51\%), dimension $6(49 \%)$, and dimensions $5(40 \%)$. Each of the dimensions is 
described below.

Dimension 3 Integration in the job post. This dimension covers aspects associated with compliance of employment rights, as well as job post and academic background coherence, and support from colleagues and conflict resolution (< T40: 51\%; > T60: $33 \%$ ).

Dimension 6 Personal development. This dimension assess the employee's achievements related to personal improvements expectations resulting from his or her work such as improvements in living standard, housing and social recognition and personal safety to face adversities (< T40: 49\%; > T60: $17 \%$ ).

Dimension 5 Well-being achieved through work. It describes factors related to the perception of the usefulness of the work performed and enjoyment of work activity through the use of skills and abilities and self-commitment. It also includes social aspects such as housing, nourishment and general health (< T40: 40\%; > T60: 31\%).

Table 3. Socio-demographic characteristics of the personnel- Jurisdiction 2

\begin{tabular}{|c|c|c|}
\hline Socio-demographic data & $f$ & $\%$ \\
\hline \multicolumn{3}{|l|}{ Gender } \\
\hline Male & 3 & 4.3 \\
\hline Female & 67 & 95.7 \\
\hline \multicolumn{3}{|l|}{ Marital status } \\
\hline Single & 27 & 38.6 \\
\hline Married & 40 & 57.1 \\
\hline Vidow/vidower & 3 & 4.3 \\
\hline \multicolumn{3}{|l|}{ Type of contract } \\
\hline Tenure & 24 & 35.3 \\
\hline Temporary & 14 & 20.6 \\
\hline Authorized & 13 & 19.1 \\
\hline Social insurance & 16 & 23.5 \\
\hline Indefinited contract & 1 & 1.5 \\
\hline \multicolumn{3}{|l|}{ Another job } \\
\hline Yes & 15 & 21.4 \\
\hline No & 55 & 78.6 \\
\hline \multicolumn{3}{|c|}{ Average age: 39 years old; range: $23-69$ years old } \\
\hline From $23-30$ years old & 19 & 27.5 \\
\hline From 31-40 years old & 27 & 39.1 \\
\hline From 41 years old or more & 23 & 33.3 \\
\hline \multicolumn{3}{|c|}{ Average working experience: 12 years; range: from 1-40 years } \\
\hline 1-4 years & 17 & 25.4 \\
\hline $5-10$ years & 21 & 31.3 \\
\hline 11 years or more & 29 & 43.3 \\
\hline \multicolumn{3}{|c|}{ Average experience years in $1^{\text {st }}$ level: 11 years; range: 1 -39 years } \\
\hline 1-4 years & 22 & 33.8 \\
\hline $5-10$ years & 17 & 26.2 \\
\hline 11 years or more & 26 & 40.0 \\
\hline
\end{tabular}

Note. Seventy nurses with Bachelor degree

Table 4. CVT mesurement

\begin{tabular}{llllllll}
\hline Score & $\begin{array}{l}\text { Dimension 1 } \\
\text { Institutional } \\
\text { support }\end{array}$ & $\begin{array}{l}\text { Dimension 2 } \\
\text { Safety at } \\
\text { work }\end{array}$ & $\begin{array}{l}\text { Dimension 3 } \\
\text { Workplace } \\
\text { inclusion }\end{array}$ & $\begin{array}{l}\text { Dimension 4 } \\
\text { Satisfaction } \\
\text { for the work }\end{array}$ & $\begin{array}{l}\text { Dimension 5 } \\
\text { Well-being achieved } \\
\text { through work }\end{array}$ & $\begin{array}{l}\text { Dimension 6 } \\
\text { Personal } \\
\text { development }\end{array}$ & $\begin{array}{l}\text { Dimension 7 } \\
\text { Free time } \\
\text { management }\end{array}$ \\
\hline > T60 & $\mathbf{5 0 . 0}$ & $\mathbf{3 8 . 6}$ & 32.9 & $\mathbf{4 8 . 6}$ & 31.4 & 3 \\
T40-T60 & 22.9 & 34.3 & 15.7 & 30.0 & 28.6 & 34.3 \\
$<$ T40 & 27.1 & 27.1 & $\mathbf{5 1 . 4}$ & 21.4 & $\mathbf{4 0 . 0}$ & $\mathbf{3 8 . 6}$ \\
\hline
\end{tabular}

Note. Seventy nurses with Bachelor degree 
On the other hand, dimensions which resulted with rates higher than T60 values were dimension 1 (50\%), dimension $4(49 \%)$, dimension $2(39 \%)$ and dimension 7 (39\%).

Dimension 1 Institutional Support. It includes aspects associated with supervision satisfaction, job assessment, and freedom of speech with superiors, as well as support, concern and recognition from superiors. In also includes promotion opportunities (> T60: 50\%; < T40: 27\%).

Dimension 4 Work satisfaction. It includes aspects such as hiring method, period, shift, and work amount. Satisfaction from duties and chores performed. Work recognition as well as freedom to use skills and the potential of professional performance (> T60: 49\%; < T40: $21 \%$ ).

Dimension 2 Feeling safe at work. This dimension assesses work procedures, income and wages received, contractual rights and work training perceived by employees (> T60: 39\%; < T40: 27\%).

Dimension 7 Free time management. It contains aspects such as free time planning, as well as balance found between work and family life (> T60: 39\%; < T40: 29\%).

While these four dimensions showed higher satisfaction rates (> T60), said rates were not over 50\%; dimension 1 was the only one to reach $50 \%$, the other three dimensions showed lower rates.

\section{Discussion}

Sociodemographic data confirmed that the Nursing profession remains a feminized profession, ${ }^{[20]}$ which could impact work life quality in the multiple roles they perform (wife, mother, housewife, employee) where she puts caring for patients, family and friends or other community members before her own needs, ${ }^{[21]}$ this is verified by the results presented in this study. Here, levels of dissatisfaction were identified in which the dimension free time management presented $38 \%$ level of satisfaction $(\mathrm{T}>60)$. This could be explained by $96 \%$ of women, who perform multiple roles sometimes with their partner's support; this aspect has been widely discussed and acknowledged in other studies. These studies point out the need to build gender equality in our society; ${ }^{[22]}$ this should be also taken into account when analyzing health service human resources and, in this case, in health clinics where the most important human resource is women power.

In Mexico, there are few studies about QWL, especially in health personnel and in Nursing; the results in this study prove that nursing personnel perceives dissatisfaction in their work life quality. These aspects have been confirmed by other studies where dissatisfaction evidence is present in several aspects of the Nursing personnel working life. ${ }^{[8,17]}$
Results show that one of the dimensions with the highest dissatisfaction is one associated with inclusion in the workplace (dimension 3), which considers aspects such as breach of labor rights. Employees show their dissatisfaction as they perceive that the terms of the contract are not being fulfilled. In this regard, in 1977 the International Labour Organization (ILO) issued Convention C149 about nursing personnel establishing standards on employment and conditions of work and life of nursing personnel. This took effect on July 11, 1979; however, this international instrument has yet to be endorsed in Mexico. ${ }^{[23]}$

This dimension also includes the relevance of academic preparation of the employee with the post that he or she occupies, where although the Mexican Official Standard NOM-019-SSA3-2013, for the Practice of nursing in the National Health System ${ }^{[24]}$ states that the managing functions are core functions of nurses with masters given that their degree of education with higher studies in a specific area allows them to take on those roles. These criteria are not yet being applied in all health clinics in the country. This is true in the case of the participants in the study sample, leading to labor dissatisfaction, because administrative tasks that are defined to be done by BSN nurses with a master degree were performed by nurses without a BSN or a master degree. This was corroborated with this sample in which nurses with a BSN or a master degree did not have an administrative position and in some of the administrative positions, the person in charge did not have a BSN degree.

This dimension covers aspects related to interpersonal relationships with colleagues, in which the lack of development in communication skills poses labor dissatisfaction as well as work stress. This is relevant because, on the one hand, there could be individual health issues and, on the other hand, there could be negative consequences in professional and work performance (absenteeism, dissatisfaction and lack of commitment). Both effects are undesirable for adversely affecting the nursing profession and the quality of care offered to the patient and family. ${ }^{[25]}$

Another dimension with great dissatisfaction is dimension 6 Personal development, which indicates dissatisfaction for not being able to achieve personal results from work as well as social recognition. These aspects have also been identified in other studies ${ }^{[6,7,22]}$ where nursing professionals in primary care perceive that the work performed is not recognized equally as the care given in ICU or emergencies.

In this regard, it is documented that nursing is a very visible and deeply unknown profession, since society still does not fully recognize the competence, autonomy and independence of nurses, there is a tendency to consider the profession as 
inferior to medicine. Thus the majority of the population ignores that nursing has its own field of competence ${ }^{[26,27]}$ which is reflected in the dissatisfaction of work life quality given that nurse professionals do not feel socially recognized for their performance.

Another dimension with dissatisfaction level is dimension 5 Well-being achieved through work, which describes factors related to the perception of the usefulness of the work performed and enjoyment of work activity through the use of skills and abilities and self-commitment. Thus showing the great need to strengthen recognition of their work as previously stated, but it also shows these professionals are not satisfied with what they are currently doing, meaning they are not satisfied with the use of their skills and expertise because the actual job does not permit them to develop as desired or because there is a lack the abilities required to develop. This aspect leads us to identify the need to reconsider the functions currently performed by nurses in the primary care level. The results were also identified in other studies such as the Association of Public Health Nursing in the United States, which redesigned their functions to ensure its contribution to achieve compliance with the essential public health functions defined in their country, thereby contributing to better health for the population. ${ }^{[2]}$

In this same dimension, dissatisfaction with housing services and features is identified, which reflects the fact that the accrued payroll is not adequate to meet basic employee needs. ${ }^{[7]}$ Although in January 2005 the nursing wages were all divided to benefit general minimum wages, which would improve wages, ${ }^{[28]}$ this is not yet reflected for all employees. This is perhaps also influenced by the hiring method, where it is proven that there are better working conditions, better social climate of work and fewer side effects for the staff with a steady contract. This means that the higher the stability in the contract, there are better working conditions, creating a satisfying working environment for employees. ${ }^{[29]}$ Both aspects (Hiring method and satisfaction for wages) are indicators for dimension 2 Feeling safe at work and dimension 4 Work Satisfaction respectively, with scores of $>$ T60 in less than $50 \%$ of the study population.

This dissatisfaction could also be explained by the heavy workload nursing staff faces, documented in other studies, ${ }^{[5-7,30,31]}$ and the lack of resources to meet the health needs of the population, also described in studies conducted in Mexico. These aspects demonstrate the need for an organization of Nursing in the primary care that allows a better distribution of personnel and resources, and a clearer definition of the roles of nursing professionals at this care level that is an essential aspect in order to ensure a suitable working environment. ${ }^{[32]}$

Published by Sciedu Press
These results are confirmed by other studies in similar contexts in Latin American, such as Peru and Chile, and other global settings such as Saudi Arabia, China and Spain, which show low job satisfaction perceived by nursing professionals. ${ }^{[11,12,33-36]}$

It is unavoidable to approach leisure time enjoyment without taking into account social aspects, such as conditions of insecurity in which the country finds itself. Public insecurity is one of the issues that has most worried the Mexican population in recent years, creating fear and uncertainty among the population. ${ }^{[37]}$ These conditions get even worse if the person lives in one of the states with the highest crime rate, as in the case of the state where the study was conducted. It is one of the most insecure in the country according to the National Institute of Statistics and Geography. ${ }^{[38]}$

On positive side, the most valued was dimension 1 Institutional support. It is interesting to point out that the aspects related to management support were included in this dimension and it was the most valued, which is contrary to what other studies show about management support receiving the lowest job satisfaction perceived by nursing personnel. ${ }^{[7,8,36]}$

\section{Conclusion}

Dissatisfaction is found in QWL of nursing staff who works in primary care. The areas of greatest dissatisfaction are: (1) Failure to comply with labor rights, such as not having health insurance because of the type of contract with certain workers and their duration (eventual workers), and low wages, do not correspond with the academic preparation or the importance of the activities of professional nursing; (2) Dissatisfaction with social recognition of the work done by the health professional, and the use of their skills and competencies of this professional, being necessary to analyze the functions currently performed by this professional in the light of the millennium goals and institutional and occupational profiles of this professional; and (3) dissatisfaction in the use of their free time, suggesting consider the gender perspective in identifying needs of human resources at the primary care level since the higher percentage of workers in this sector are women and housewives. Among the areas identified as opportunities for improvement they are related to administrative support, monitoring processes and communication that exists with superiors.

Since this is one of the first studies in our context it needs to generate more knowledge in this area, and not only focused on describing the quality of life, but also to identify and analyze factors that may be contributing to improve or not the QWL not only for nursing staff but for all members of the health team, this in order to design effective strate- 
gies for better working conditions. Which not only benefit workers, but the entire population that would receive better services, which would be reflected in a better approach to current health situations.

\section{Limitations of the study}

The sample size does not allow to generalize the results, however, it can be assumed that similar studies with similar results would be found, because the working conditions and the functions performed by these professionals are equal in other contexts.

In the present study we have not analysis of relationship between the QWL and other important variables such as sex, marital status, working time, since the only one main objective was to describe the QWL, as one of the first studies in this area, it would be necessary to make further studies exploring these relationships.

\section{REFERENCES}

[1] World Health Organization. The World Health Report 2008: primary health care now more than ever. Geneva, Switzerland: World Health Organization; 2008.

[2] Pan American Health Organization and World Health Organization [Internet]. Public health nursing and essential functions of public health: basis for professional practice in the XXI century. 2001 [Cited 2015 Sept]. Available from: http://www.ops.org.bo/tex tocompleto/ise20596.pdf. Spanish.

[3] Torres EM, Dandicourt TC, Rodríguez CA. Nursing roles in primary health care. Rev Cubana Med Gen Integr. 2005; 21: 3-4. Spanish.

[4] De Bortoli CS. Strategy for universal access to health and universal health coverage and the contribution of the International Nursing Networks. Rev Latino-Am Enfermagem. 2014; 22(6): 891-2. http://dx.doi.org/10.1590/0104-1169.0000.2502

[5] Nigenda G, Maga-a VL, Cooper K, et al. Recent developments in Public Health Nursing in the Americas. Int J Environ Res Public Health. 2010; 7: 729-50. http://dx.doi.org/10.3390/ijerp h7030729

[6] Pe-arrieta CM, Mier N, Gonzalez QN, et al. Role and working conditions of nurses in public health in Mexico and Peru: a binational qualitative study. J Nurs Manag. 2013; 21(8): 1034-43. http://dx.doi.org/10.1111/j.1365-2834.2012.01465.x

[7] World Bank. Voices of the poor: can anyone hear us? Vol.1. Washington, DC: World Bank. 1999.

[8] Sosa CO, Cheverría RS, Rodríguez PM. Quality of professional life of nursing personnel. Rev Enferm Inst Mex Seguro. 2010; 18(3): 153-8. Spanish.

[9] Makinen A, Kivimaki M, Elovainio M, et al. Organization of nursing care as a determinant of job satisfaction among hospital nurses. Journal of Nursing Management. 2003; 11: 299-306. http://dx.doi.org/10.1046/j.1365-2834.2003.00399.x

[10] Hernández JV, Quintana TL, Mederos TR, et al. Motivation, satisfaction at work, leadership and their relation with the service quality. Rev Cub Med Mil. 2009; 38(1). Spanish.

[11] Ge C, Fu J, Chang Y, et al. Factors associated with job satisfaction among Chinese community health workers: a cross-sectional study. BMC Public Health. 2011; 11(884). http://dx .doi.org/10.11 86/1471-2458-11-884

[12] Graham K, Davies B, Woodend A, et al. Impacting Canadian public health nurses' job satisfaction. Can J Public Health. 2011; 102(6): 427-31. PMid: 22164552.

[13] Bakker A, Killmer C, Siegrist J, et al. Efford-reward imbalance and burnout among nurses. Journal of Advanced Nursing. 2000; 31(4): 884-91. PMid: 10759985. http://dx.doi.org/10.1046/j.136 $5-2648.2000 .01361 . x$
[14] Ministry of health. Health sector program. 2013-2018. $1^{\text {st }}$ ed. Mexico, DF: IEPSA; 2013. Spanish.

[15] Alcalde-Rabanal JE, Bärnighausen T, Nigenda-López G, et al. Human resources needed to affter health prevention and promotion to adults in primary health care. Salud Publica Mex. 2013; 55(3): 301-9. PMid: 23912543.

[16] Pan American Health Organization. Handbook for Measurement and Monitoring Indicators of the Regional Goals for Human Resources for Health: A Shared Commitment. Washington, D.C.: PAHO; 2011.

[17] González BR, Hidalgo SG, Salazar EJ, et al. Development and validation of an instrument to measure Quality of Work Life "CVTGOHISALO". Cienc Trab. 2010; 36: 332-40. Spanish.

[18] Herrera SR, Cassals VM. Some factors influencing on the quality of the nursing working life. Rev Cubana Enfermer. 2005; 21(1).

[19] González BR, Hidalgo SG, Salazar EJG, et al. Instrument for measuring quality of life in the CVT - GOHISALO, Working Manual for application and interpretation. Guadalajara, México: Ediciones de la Noche; 2009. Spanish.

[20] Lorente MB. Gender, science and work. Feminized professions and practices of care and social assistance. Scripta Ethnologica [Internet]. 2004; 26: 39-53. Available from: http: //www.redalyc.org/ar ticulo. oa?id=14802602. Spanish.

[21] Quintana ZM, Paravic KT. Quality of work life in nursing staff. Rev Bras Enferm. 2014; 67(2): 302-5. http://dx.doi.org/10.5935 /0034-7167.20140041

[22] Casta-eda HM. The triad of mexican culture, gender and nursing as silent causes of burnout syndrome [Doctoral Thesis]. Alicante, Spain: University of Alicante; 2012.

[23] Pan American Health Organization. Strengthening Health Systems Area. Regulation of nursing in Latin America. Human Resources for Health series No. 56. Washington, DC: PAHO; 2011. Spanish.

[24] Official Mexican Standard NOM-019-SSA3-2013, For Nursing Practice in the National Health System. Official Journal of the Federation; 2013. Spanish.

[25] Garcés FE. Conceptual delimitation of the burnout construct. Información Psicológica. 1998; 68: 15-23. Spanish.

[26] Calvo CM. Social image of nursing and public communication satrategies to obtain a positive image. Index Enferm. 2011; 20(3): 184-8. http://dx.doi.org/10.4321/S1132-1296201100020 0010

[27] Errasti-Ibarrondo B, Arantzamendi-Solabarrieta M, Canga-Armayor N. The public image of nursing: a profession to learn about. An Sist Sanit Navar. 2012; 35(2): 269-83. http://dx.doi.org/10.4321 /S1137-66272012000200009 
[28] Torres LM. Tab Divestiture of general minimum wages to the profession of nursing degree. Acontecer Academico. 2005; 3(7): 4-5. Spanish.

[29] Uribe-Rodríguez A, Garrido-Pinzón J, Rodríguez A. Influence of the Type of Contracting on the Quality of Working Life: Signs of the Organizational Capitalism. Revista Virtual Universidad Católica del Norte. $2011 ; 33: 1-16$

[30] Ninel Mininel V, Felli V, da Silva E, et al. Workloads, processes of wear and absenteeism-disease in nursing staff. Rev Latino-Am Enfermagem. 2013; 21(6): 1290-7. Spanish. http://dx.doi.org /10.1590/0104-1169.2992.2366

[31] Flores N, Jenaro C, Cruz M, et al. Burnout Syndrome and Quality of Working Life among Health Services Professionals. Pensando Psicología. 2013; 9(16): 7-21.

[32] Lape-a MY. Phenomenological study of labor relationships: the look of nurses from different units of the general hospital Santa Barbara in Soria [Doctoral Thesis]. Alicante, Spain: University of Alicante; 2012. Spanish.
[33] Pe-arrieta-de Córdova I, Santiago-Abregú S, Krederdt-raujo S, et al. Validation tool: quality of life at work in the first level nursing care. Rev enferm Herediana. 2014; 7(2): 124-31.

[34] Delgado D, Aguilera M, Delgado F, et al. Quality of life at work and working conditions in auxiliary sterilization. Cienc Trab. 2013; 15(48): 148-51.http://dx.doi.org/10.4067/S0718-2449201 3000300007

[35] Almalki M, FitzGerald G, Clark M. Quality of work life among primary health care nurses in the Jazan region, Saudi Arabia: a cross-sectional study. Human Resources for Health. 2012; 10(30). http://dx.doi.org/10.1186/1478-4491-10-30

[36] Fernández AA, Santa CE, Casado OM. Quality of Professional life of nurses in primary care in Soria. Biblioteca Lascasas. 2007; 3(1). Spanish.

[37] Tapia PJ. Public insecurity: Causes and Consequences. El Cotidiano. 2013(July-August): 103-12. Spanish.

[38] National Census of Government, Public Security and State Prison System 2013 [Internet]. 2013. Available at: http://www.inegi. org. $\mathrm{mx} / \mathrm{est} / \mathrm{lista}$ _cubos/consulta. aspx? $\mathrm{p}=$ gob\&c $=3$ 